\title{
Accidental gonococcal infection of a child's eye Unusual source of infection
}

\author{
J. O. DOYLE \\ Southampton Special Treatment Centre, Bullar Street, Southampton
}

In the past 2 years several cases of gonococcal infection of the eyes in children have been reportedfour cases in the U.S.A. (Shore and Winkelstein, 1971), and two cases in Great Britain (Doyle, 1972). In three of the American cases (boys) only the eyes were infected; the fourth case, a girl, also had gonococcal vaginitis. In the two British cases (boys) only the eyes were infected.

The following patient seen in Southampton is of interest in that the source of infection was unusual.

\section{Case report}

A male infant aged 8 months was referred to the Southampton Special Clinic on February 24, 1972, by the Casualty Officer, Southampton Eye Hospital with gonococcal conjunctivitis in the left eye. Neisseria gonorrhoeae was isolated on culture from the left eye on February 23, 1972. Penicillin eye drops were instilled at the Eye Hospital. The baby was given 300,000 units procaine penicillin intramuscularly on February 24 and this dosage was repeated on the following day. The conjunctivitis had cleared up 4 days later. The parents were instructed to bring the baby for follow-up, but in spite of visits and letters did not bring him again until April 21, 1972, when the left eye appeared to be normal, and a culture from the eye gave no growth. The child's parents were interviewed in the Special Clinic at the initial attendance.

\section{MOTHER}

The mother stated that she had had a vaginal discharge before the baby was born and that this had been treated with pessaries after which she was symptom-free. She mentioned that she had three young sisters as lodgers who from time to time nursed the baby.

Examination There was a profuse vaginal discharge and cervicitis. Urethral and cervical smears and cultures showed no evidence of a gonococcal infection. No treatment was given and further smears and cultures 4 days later were again negative for the gonococcus. She then defaulted and in spite of letters and visits did not attend again until April 21, 1972, when urethral and cervical smears were negative.

\section{FATHER}

The father had no symptoms. He admitted extramarital coitus, but this had been over a year ago.

Examination $\mathrm{He}$ had a mucopurulent urethral discharge. Urethral smear revealed pus cells only; culture for the gonococcus was negative. He was seen again 4 days later. Repeat urethral smear and culture were again negative for the gonococcus. He then defaulted and did not attend again until April 21, 1972, when he was asymptomatic. No urethral discharge was detected and the urine was clear.

In view of the negative findings in the parents, the three young girl lodgers who nursed the baby occasionally were examined.

\section{LODGER ONE}

The first of the girls, aged 18 yrs, was seen on February 29, 1972. She had no symptoms, but examination showed a mild cervicitis. Urethral and cervical smears and cultures were negative for the gonococcus. A wet smear revealed trichomonads but no monilia. She was given a course of Flagyl. She then defaulted and in spite of letters and visits did not attend again until April 19, 1972, when she was found to have scabies. Smears and cultures again gave negative results.

\section{LODGER TWO}

The next sister, aged 21 years, also attended on February 29,1972 . She had been lodging in the same house as the baby but had recently left. She complained of severe abdominal pain of $24 \mathrm{hrs}$ ' duration, and had been seen by the family doctor 1 hour previously when Septrin tablets were prescribed. She admitted coitus 5 days previously with her regular boy friend but denied having had any other consorts during the past year.

There was marked tubal tenderness. The temperature was $100^{\circ} \mathrm{F}$. and the pulse rate 92 . A mucopurulent cervical discharge was present. A cervical smear showed numerous 
Gram-negative intracellular diplococci but cultures were negative.

A diagnosis of gonococcal salpingitis was made. She stated that she had nursed the baby but did not bath or cuddle him. She had her own towel and left it hanging in the bathroom.

Her regular boy friend attended the clinic on March 14, 1972. He had a urethral discharge of a few days' duration. A urethral smear revealed presumed gonococci, but the culture was negative.

\section{LODGER THREE}

The remaining sister, aged 16 years, who was seen on March 1, 1972, was symptom free. She was found to have moniliasis, but urethral and cervical smears and cultures were negative for the gonococcus. She defaulted until April 19, 1972, when she was found to have scabies. Smears and cultures again gave negative results.

\section{Summary and conclusions}

A case of accidental gonococcal infection of the eye in an 8-month-old baby is described. It would appear that a lodger with gonococcal salpingitis was the source of the baby's infection. It is feasible that this lodger's towel, which she hung in the bathroom, had been used for the baby and had infected his eye.

When the parents of a child suffering from gonorrhoea are found to be free of infection, it is of the utmost importance to examine other members of the household in an endeavour to discover the source of the infection.

I wish to thank Drs. R. M. Warren and C. J. S. Holdsworth for their assistance in the preparation of this paper.

\section{References}

DOYLE, J. O. (1972) Brit. med. F., 1, 88

SHORE, W. B., and WINKELstein, J. A. (1971) f. Pediat., 79, 661

Infection gonococcique accidentelle de l'oeil chez un enfant. Source inhabituelle de l'infection

\section{SOMMAIRE}

On décrit le cas d'une infection gonococcique accidentelle de l'oeil chez un enfant de 8 mois. Il semble que l'origine de l'infection de cet enfant puisse être une logeuse atteinte de salpingite gonococcique. Il est probable que la serviette de la logeuse, qui avait été accrochée dans la salle de bain, a été utilisée pour l'enfant et a infecté l'oeil.

Quand les parents d'un enfant atteint de gonococcie sont trouvés indemnes d'infection, il est de la plus grande importance d'examiner les autres membres de la maisonnée pour tenter de découvrir la source de l'infection. 